Ann. Biol. anim. Bioch. Biophys., 1978, 18 (3), 749-758.

\title{
Alkaline phosphatase in human, cow and sheep milks : molecular and catalytic properties and metal ion action.
}

\author{
par G. LINDEN, C. ALAIS
}

Laboratoire de Biochimie, Universifé de Nancy I

54037 Noncy Cedex, France.

Summary. A dominant fraction of milk alkaline phosphatase was isolated during purification. The fraction had almost identical molecular and kinetic properties in the human, bovine and ovine species, i. e. molecular mass of 170000 daltons, optimum $\mathrm{pH}$, absence of substrate specificity. The variation of $\mathrm{Km}$ and $\mathrm{V}$ with the $\mathrm{pH}$ revealed two ionizable group pK values of 8.6 and 9.0 to 9.3 , thus indicating that the active center groups were identical for human, bovine and ovine enzymes. The 3 phosphatases required two types of metals for maximum activity-zinc which was essential and magnesium which was stimulatory. $\mathrm{Mg}^{2+}$ stimulation was $\mathrm{pH}$-dependent ; the $\mathrm{Mg}^{2+}$ fixed slowly at weakly alkaline $\mathrm{pH}$ and caused a conformational change. The only apparent catalytic effect was an increase of the maximal rate, $\mathrm{V}$. The $\mathrm{Mg}^{2+}$ site was different from the substrate fixation site. $\mathrm{Mg}^{2+}$ could be replaced by $\mathrm{Mn}^{2+}, \mathrm{Co}^{2+}$ and $\mathrm{Ni}^{2+} ; \mathrm{Zn}^{2+}$ could also be fixed but it had an inhibitory effect. Reconsitution experiments using human, sheep and bovine apophosphatase indicated that $\mathrm{Mg}^{2+}$ alone did not regenerate the activity and thus could not replace $\mathrm{Zn}^{2+}$ at the zinc site. Likewise $\mathrm{Zn}^{2+}$ alone could not regenerate the activity and enters in competition with $\mathrm{Mg}^{2+}$ when there was an excess ; $\mathrm{Zn}^{2+}$ had a higher affinity than $\mathrm{Mg}^{2+}$ for the magnesium site. Cobalt could replace both zinc and magnesium.

\section{Introduction.}

Mammal alkaline phosphatases (orthophosphoric monoester phosphohydrolase, EC. 3.1.3.1.) catalyzing the hydrolysis of most orthophosphoric esters and inorganic and organic pyrophosphates with optimum activity at alkaline $\mathrm{pH}$ are found in varying amounts in many tissues or secretions (Fernley, 1971).

The best known mammal alkaline phosphatases are of intestinal or placental origin because those organs are the richest in enzyme. Kidney, liver, brain and bone phosphatases have also been studied and found to have some different properties than the intestinal or placental enzymes.

Milk alkaline phosphatase, which does not belong to the intestinal and placental phosphatase group, is of great interest because it is used as an assay in the control of industrial pasteurization of dairy products (Sanders, 1949). Its biochemistry is especially fascinating since the phosphatase, totally inactivated by heat treatment, progressively recovers some of its activity in certain conditions. The purification and study of the molecular and kinetic properties of alkaline phosphatase in cow milk were des- 
cribed by Morton (1953). Since that preliminary report, this milk enzyme has only been studied by a few authors. Besides some work on the properties of cow milk alkaline phosphatase (Linden, 1977), the human and sheep milk enzyme has been studied in our laboratory (Michalowski, 1977). These biochemical studies were done taking into consideration the medium from which the enzyme was extracted. In this report we review and compare the data.

\section{Material and methods.}

The fat of individual human milks and of a mixture of sheep milks was separated by centrifugation and the human and sheep alkaline phosphatases extracted with n-butanol using the technique of Morton (1953). Cow milk alkaline phosphatase was extracted from butter milk by the same method. Purification was carried out as follows : precipitation with ammonium sulfate, filtration on Sephadex G-200 and chromatography on DEAE-cellulose. These techniques were used on different extracts and permitted us to obtain phosphatase preparations from cow, sheep and human milks having maximum specific activities of 1250,54 and $0.5 \mathrm{IU} / \mathrm{mg}$ protein, respectively.

Molecular mass was determined by gel filtration with the elution volume method of Andrews (1964) using a Sephadex G-200 column equilibrated with $100 \mathrm{mM}$ Tris- $\mathrm{HCl}$ buffer at $8.0 \mathrm{pH}$. Molecular mass estimation by analytical centrifugation was done by direct measurement using a multichannel cell and by determining sedimentation and Schlieren optic diffusion coefficients. Polyacrylamide gel electrophoresis with sodium dodecyl sulfate was carried out using the method of Weber and Osborn (1969). The analytic electrophoreses were carried out on $7 \mathrm{p}$. 100 polyacrylamide gel with the technique of Davis (1964) in a Tris-HCl buffer at $8.5 \mathrm{pH}(3 \mathrm{~mA}$ per tube for $105 \mathrm{mn})$. For the study of phosphatase « remetallization », previous demetallization was done by 2-hr incubation at $20^{\circ} \mathrm{C}$ in the presence of $1 \mathrm{mM}$ EDTA in $0.05 \mathrm{M}$ Tris- $\mathrm{HCl}$ buffer at $8.0 \mathrm{pH}$. Apophosphatase was then reactivated at $20^{\circ} \mathrm{C}$ in the same buffer by adding divalent cations at a $0.5 \mathrm{mM}$ concentration. Enzyme activity was measured as previously described (Linden and Alais, 1976).

\section{Results and discussion.}

\section{Molecular properties.}

Molecular mass. - Phosphatase of human, cow and sheep milks have a very similar molecular mass (table 1). A comparative study of the molecular masses of mammalian alkaline phosphatases shows that milk alkaline phosphatase belongs to the same group as kidney, brain and liver alkaline phosphatase which have a molecular mass higher than 150000 daltons (Linden, 1977). Another group includes intestinal and placental alkaline phosphatase with a molecular mass between 116000 and 140000 daltons.

Subunit structure. - Polyacrylamide gel electrophoresis of cow milk alkaline phosphatase treated with sodium dodecyl sulfate shows that the enzyme is a dimer composed of two identical or very similar monomers. Most alkaline phosphatases 
isolated up to now have a quaternary structure resulting from the association of 2 subunits. Considering their molecular mass, it is probable that human and sheep milk alkaline phosphatases also have this type of structure.

\section{TABLE 1}

Molecular mass of alkaline phosphatase in human, cow and sheep milks

\begin{tabular}{cc}
\hline Species & Molecular mass \\
\hline Human... & $160000^{a}$ \\
Ovine ... & $160000^{a}$ \\
Bovine ... & $190000^{a}$ \\
- & $16000^{b}$ \\
- & $170000^{c}$ \\
- & $170000^{d}$ \\
& $161000^{e}$ \\
\hline
\end{tabular}

a Dextran gel chromatography.

$b$ Equilibrium Sedimentation.

- Analytical centrifugation at a speed of : $59780 \mathrm{rpm}-\mathrm{S}_{20, \mathrm{w}}^{0}=6.0 \mathrm{~S} ; \mathrm{D}^{0}{ }_{20, \mathrm{w}}=3.4 .10^{-7} \mathrm{~cm}^{2} / \mathrm{s}$.

d Polyacrylamide gel electrophoresis.

- From the amino acid composition. Does not include the carbohydrate fraction.

Molecular species and electrophoretic behavior. - Milk alkaline phosphatase is polymorphic ; the work of Lefranc and Han (1967) showed that cow milk has 2 isoenzymes and even 4, according to Peereboom (1968) and Buruiana and Dema (1969). When purifying human or sheep milk alkaline phosphatase, Michalowski (1977) noted several peaks or activity strips during chromatography or electrophoresis. He showed that the heterogeneity of the phosphatase results from a balance between

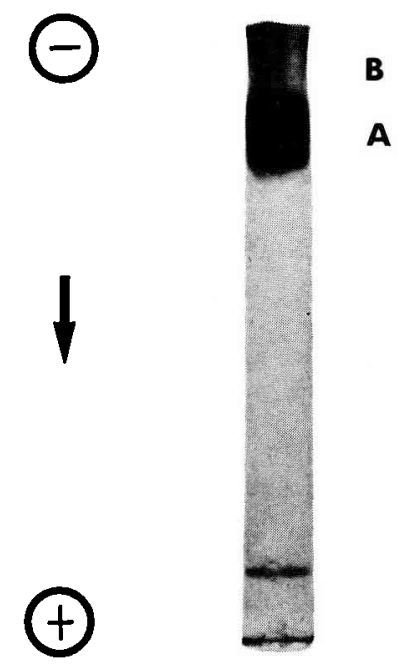

FIG. 1. - Polyocrylamide gel electrophoresis of a row alkaline phosphatase extract of cow milk. Alkaline phosphatase electrophoregrams of human and sheep milk are identical. Phosphatase activity was revealed with $a \alpha$-naphtylphosphate solution and $\alpha$-naphtol staining released by variamine blue. The lower strip is the migration standard. 
the various molecular species, the most stable ones having the lowest molecular mass (160 000 daltons). Ghosh and Fishman (1968) studying an extract of placental alkaline phosphatase made similar observations. On the other hand, we only observed a single enzymatic form in cow alkaline phosphatase preparations obtained from buttermilk.

Polyacrylamide gel electrophoreses confirm these results and show two activity strips in raw extracts of alkaline phosphatase prepared from human, cow or sheep milks (fig. 1). The most intense strip corresponds to the dimeric form and has the molecular characteristics of the A fraction (Lefranc and Han, 1967) or of the $\alpha$ isoenzyme (Peereboom, 1968). Above this zone of activity, we noted a less active, more diffuse second strip which corresponded to the B fraction of Lefranc and Han (1967) or to the $\beta$-isoenzyme of Peereboom (1968). This isoenzyme would be a polymer of the other isoenzyme and would remain more closely associated with the fat globule surface than that one (Linden and Ged, 1976).

Thermostability. - The study of heat denaturation may be used to compare several alkaline phosphatase. Thus, Moss and Whitby (1975) differentiated bone, liver and intestinal phosphatases in blood serum. The raw human and sheep extracts have better stabili ty when heated at $72{ }^{\circ} \mathrm{C}$ than purified sheep and cow enzymes (fig. 2 ).

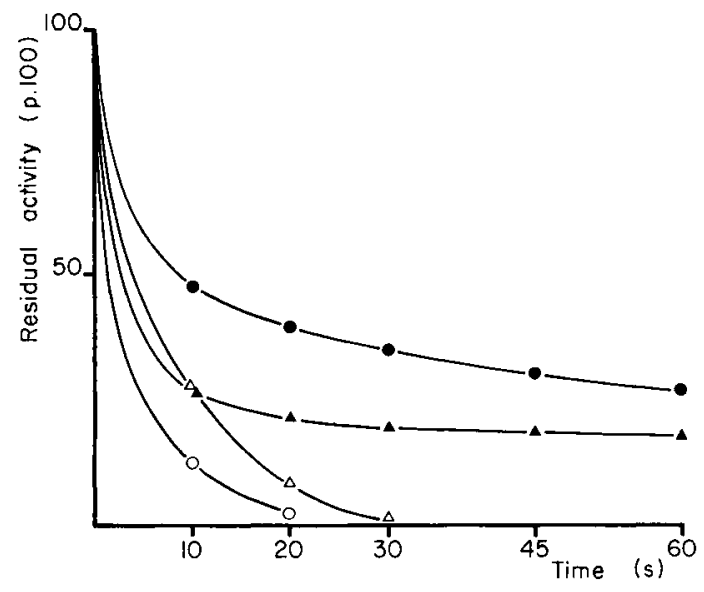

FIG. 2. - Heat denaturation of alkaline phosphatases in human, cow and sheep milks of $72^{\circ} \mathrm{C}$.

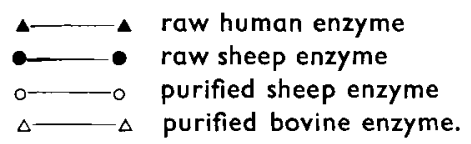

This difference does not seem to be a molecular characteristic, but probably depends on the protein environment; the phosphatase becomes progressively thermolabile in the presence of increasing $\mathrm{NaCl}$ concentration. The half-life of milk alkaline phosphatase at $55^{\circ} \mathrm{C}$ is very similar to those of the kidney, liver and brain enzymes and even to that of the intestine, but it is very different from the values given for bone tissue enzyme (low resistance) and from that of the human placenta (high resistance). 
The assay of milk alkaline phosphatase activity is used in the control of industrial pasteurization of dairy products (Sanders, 1949). After treatment at $72{ }^{\circ} \mathrm{C}$ for $15 \mathrm{~s}$ the enzyme becomes totally inactive. However, we have noted that there is still residual activity after $15 \mathrm{~s}$ of heating at this temperature (fig. 2). The more protein in the sample, the higher is this activity. Purified enzyme sensitivity thus is similar to that of the original milk enzyme when the latter is integrated into the membranous lipoprotein structure of fat globules.

\section{Catalytic characteristics.}

Alkaline phosphatases of human, cow and sheep milks have the essentia! characteristics of phosphatases, i. e. substrate specificity is absent, catalytic activity varies considerably with test conditions and pyrophosphatasic and phosphatotransferring activity is apparent.

Absence of substrate specificity. - Bovine alkaline phosphatase activity lacks substrate specificity (Linden and Alais, 1976). We have confirmed this with human and sheep phosphatases; the various preparations have the same apparent affinity for alcohol, phenol and hemiacetal esters. However, as for the other alkaline phosphatases, affinity for organic substrates such as p-nitrophenylphosphate, $\alpha$-naphtylphosphate is very high. Biological type phosphoric esters are hydrolyzed in the zone of their optimum $\mathrm{pH}$ at a rate which may vary by a factor of 6.

The presence of $\mathrm{Mg}^{2+}(1 \mathrm{mM})$ in the reactive medium has no effect on the Michaelis constant. On the other hand, the increase of maximal hydrolysis rates varies depending on the phosphoric ester, thus indicating that the $\mathrm{Mg}^{2+}$ site is different from the site of substrate fixation. The maximal rate of pyrophosphate hydrolysis is reached with $\mathrm{pH}$ values close to 7 ; in the 9 to $10 \mathrm{pH}$ zone, $\mathrm{V}$ is very low.

Optimum $\mathrm{pH}$. - Figure $3 \mathrm{~A}$ shows that ionic effect on maximal hydrolysis rate is greatest at a $\mathrm{NaCl}$ concentration of $0.4 \mathrm{M}$; at $10 \mathrm{pH}$, ionic force sensitivity is a little less than at $8.5 \mathrm{pH}$. It is well known that the nature and concentration of the substrate constitue the main causes of optimum $\mathrm{pH}$ variation. Figure $3 \mathrm{~B}$ shows the difference between the optimum $\mathrm{pH}$ of $\mathrm{p}$-nitrophenylphosphate hydrolysis (about $10 \mathrm{pH}$ ) and that of $\beta$-glycerophosphate (about $9 \mathrm{pH}$ ). Optimum $\mathrm{pH}$ values of bovine, sheep and human enzymes are very similar to those of these 2 substrates. These values agree with those of the bovine brain (Brunel, 1972) and kidney (Helove, 1974).

Determination of $\mathrm{Km}$ and $\mathrm{V}$ and variation in relation to $\mathrm{pH}$. - The values of Michaelis constants for human, bovine and sheep phosphatases are very similar. The deviations noted with the phosphoric esters of glycerol, glucose, serine and threonine are very low. For the 3 enzymes, $\mathrm{Km}$ value increases with the $\mathrm{pH}$, which means that the apparent affinity of the enzyme for the substrate decreases when hydrolysis rate increases. This is one of the classic properties of all alkaline phosphatases.

The Dixon diagram, $K m=f(p H)$, presents an inflexion in the slope of the 3 phosphatases at $8.6 \mathrm{pH}$. Depending on the enzyme, the curves, $\log V=f(\mathrm{pH})$, show a pK between 9 and 9.3 in the ES complex of the $\mathrm{pH}$ interval studied (fig. 4). This study shows the importance of 2 ionizable groups essential to human, bovine and sheep enzyme activity. Severa! amino acid residues may be implicated by the pK values 


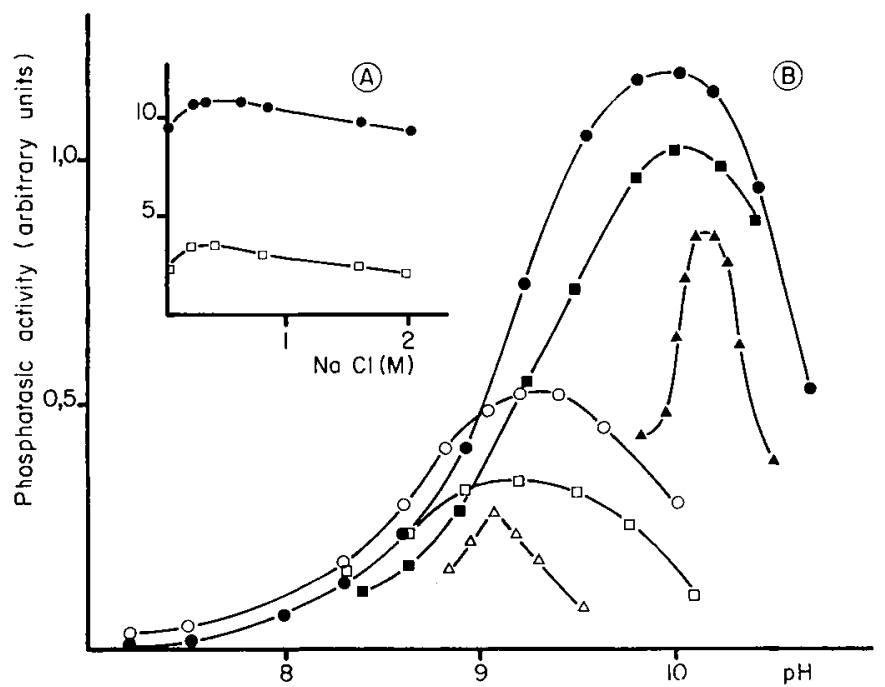

FIG. 3 A. - Effect of ionic force on maximal rate of p-nitrophenylphosphate hydrolysis by cow milk phosphatase at $37{ }^{\circ} \mathrm{C}$.

$\square \quad 8.5 \mathrm{pH}$ in $50 \mathrm{mM}$ Tris- $\mathrm{HCl}$ buffer, $1 \mathrm{mM} \mathrm{Mg}^{2+}$

- $10 \mathrm{pH}$ in $50 \mathrm{mM}$ borate buffer, $1 \mathrm{mM} \mathrm{Mg}^{2+}$.

FIG. 3 B. - Optimum pH of alkaline phosphatase action on p-nitrophenylphosphate and $\beta$-glycerophosphate using milk from different species.

- sheep p-nitrophenylphosphate-enzyme

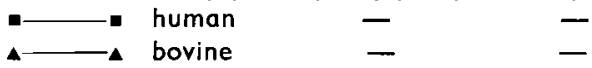

$\circ$ sheep $\beta$-glycerophosphate-enzyme

$\begin{array}{llll}\square-\square & \text { human } & - & - \\ -\triangle & \text { bovine } & -\end{array}$

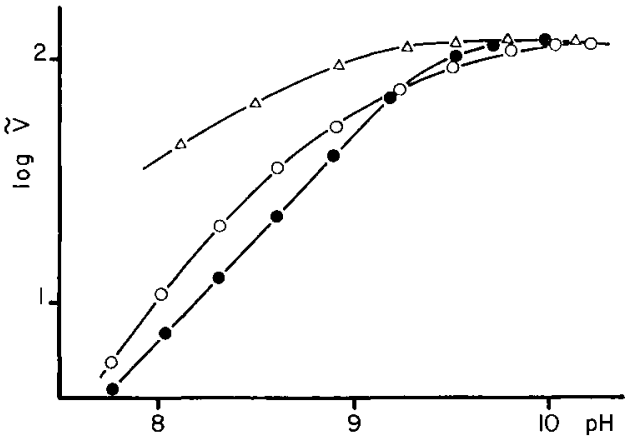

FIG. 4. - Variation of logarithm of maximum p-nitrophenylphosphate hydrolysis rate in relation to $\mathrm{pH}$.

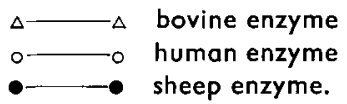


determined. We will see later that at its active center, the enzyme contains zinc, and one of the $2 \mathrm{pK}$ 's is perhaps due to the ionization of a water molecule coordinated to a zinc atom.

Other alkaline phosphatases as those of the chicken intestine and pig kidney have 2 essential ionization groups which are shifted toward more acid $\mathrm{pH}$ 's than those of milk enzymes : 8.1 and 8.6 for intestinal enzyme (Hinberg and Laidler, 1973), 7.9 and 8.7 for that of the kidney (Hiwada and Wachsmuth, 1974).

\section{Metalloprotein character of alkaline phosphatase and metallic ion action.}

Role of metals. - The action of metals on alkaline phosphatase activity has been studied by many authors with contradictory results. We therefore wish to review their conclusions. The known alkaline phosphatases, whether of bacterial or animal origin, require zinc for their activity. They may be classed into 2 groups according to $\mathrm{Mg}^{2+}$ sensitivity : those slightly or not activated by $\mathrm{Mg}^{2+}(E$. coli, enzymes in calf intestine and human placenta) and those strongly stimulated by $\mathrm{Mg}^{2+}$ as the enzyme of bovine brain (Brunel and Cathala, 1972) and kidney (Cathala ef al., 1975), pig kidney (Ahlers, 1974) and rat placenta (Petitclerc et al., 1975).

In a previous report (Linden et al., 1977) we studied the role of metals in the alkaline phosphatase activity of cow milk. In this report we describe the essential characteristics of bivalent ion activation and regeneration in the 3 enzyme preparations.

$\mathrm{Mg}^{2+}$ activation. - As the alkaline phosphatase of cow milk, human and sheep enzymes belong to the phosphatase group strongly stimulated by $\mathrm{Mg}$. The more the enzyme is purified, the stronger is the stimulus. Purification is accompanied by progressive loss of magnesium which dissociates by dilution. The activation factor is 4 at $10 \mathrm{pH}$ for the best purified human enzyme, 12 for the ewe enzyme and 18 for that of cow. This activation factor naturally depends on the amount of purified enzyme residual activity and thus on the amount of residual $\mathrm{Mg}^{2+}$. The enzyme stimulation factor is also a result of assay medium $\mathrm{pH}$. The more alkaline the $\mathrm{pH}$, the higher the stimulation factor of each enzyme, which reaches a maximum at about $10 \mathrm{pH}$. Moreover, a kinetic study of $\mathrm{Mg}^{2+}$ activation shows that human and sheep enzymes behave like the bovine enzyme, i. e. $\mathrm{Mg}^{2+}$ is fixed slowly when the $\mathrm{pH}$ is only slightly alkaline.

Effect of other bivalent cations. - Several cations other than $\mathrm{Mg}^{2+}$ may stimulate milk alkaline phosphatase. $\mathrm{Mn}^{2+}, \mathrm{Co}^{2+}, \mathrm{Ni}^{2+}$ produce a strong reaction which however is weaker than that of $\mathrm{Mg}^{2+}$. The relative activation factor for these various cations is analogous for human, sheep and bovine enzymes. This factor may be affected by the type of buffer used and by that fact that $\mathrm{Ca}^{2+}$ has very little effect. In any case, zinc acts as an inhibitor at a $1 \mathrm{mM}$ concentration. Moreover, $\mathrm{Mn}^{2+}$ becomes an inhibitor at a concentration higher than $1 \mathrm{mM}$. This is probably due to the replacement of zinc by manganese at the active site (Linden et al., 1977).

Reactivation with $\mathrm{Zn}^{2+}, \mathrm{Mg}^{2+}$ and other metals. - EDTA phosphatase inhibition is reversible. $U_{p}$ to 80 p. 100 of the initial activity is recovered by apoenzyme preincubation with increasing amounts of $\mathrm{Zn}^{2+}$. However, apoenzyme incubation in the presence of a too high $\mathrm{Zn}^{2+}$ concentration induces weak activity. This observation suggests that $\mathrm{Zn}^{2+}$ may not only occupy its own site but also that of $\mathrm{Mg}^{2+}$; this is expressed by an inhibitory effect. The inhibition of the original human, bovine of sheep enzyme by 
$\mathrm{Zn}^{2+}$ in the presence of different $\mathrm{Mg}^{2+}$ concentrations indicates $\mathrm{Zn}^{2+}$ and $\mathrm{Mg}^{2+}$ competition ; the inhibitory effect is weaker when $\mathrm{Mg}^{2+}$ is higher. $\mathrm{Zn}^{2+}$ inhibition may be totally reversed by magnesium saturation. The apoenzyme may be remetallized by other metals; the values in table 2 show the maximum reactivation for a metallic cation concentration of $0.5 \mathrm{mM}$.

TABLE 2

Relative metallophosphatase activity of $\mathrm{Mg}^{2+}$-stimulated milk

\begin{tabular}{|c|c|c|c|}
\hline $\mathrm{Me}^{2+}$ phosphatases & Human & Sheep & Cow \\
\hline 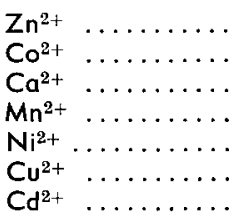 & $\begin{array}{r}100 \\
45 \\
5 \\
2 \\
0 \\
0 \\
0\end{array}$ & $\begin{array}{r}100 \\
50 \\
6 \\
2 \\
0 \\
0 \\
0\end{array}$ & $\begin{array}{r}100 \\
41 \\
5 \\
2 \\
0 \\
0 \\
0\end{array}$ \\
\hline
\end{tabular}

This comparative study shows that reconstituted milk metalloenzymes are not significantly different. $\mathrm{Zn}^{2+}$ phosphatases having strong activity are used as a reference. Aside from $\mathrm{Co}^{2+}$, the other cations used regenerate phosphatases weakly or not at all. Two types of cation fixation sites are thus required for the optimal activity of milk alkaline phosphatase, i. e. the $\mathrm{Zn}^{2+}$ site and the $\mathrm{Mg}^{2+}$ site.

\section{Conclusion.}

This report demonstrates that phosphatases of human, cow and sheep milks have markedly similar molecular mass, thermoresistance, optimum $\mathrm{pH}, \mathrm{Km}$ and ionization pK. The results obtained on the various fractions of human or ewe phosphatase elucidate the problem of heterogeneity and indicate that the human and sheep variants of

TABLE 3

Effect of fixation of various metallic cations on alkaline phosphatases of human, bovine and sheep milks

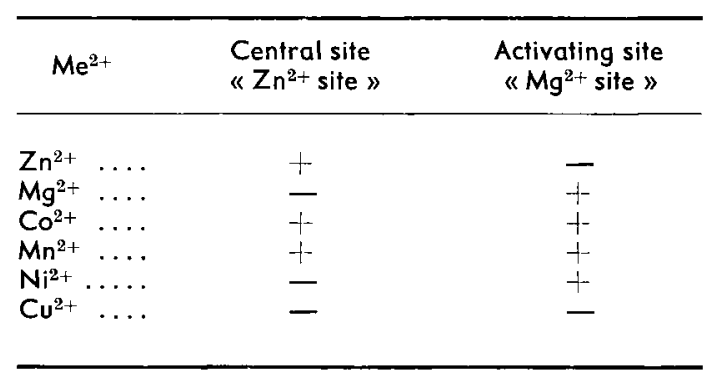

+ : stimulator ; - : inhibitor. 
high molecular mass are composed of the same dimer having a mass of 160000 to 170000 daltons. Genetic polymorphism of the enzyme extracted from fat of a mixture of milks is doubtful.

The action of different metals on milk alkaline phosphatase is very similar to that observed on bovine kidney enzyme (Cathala et al., 1975). The result of fixing metal cations on human, bovine and sheep enzymes is shown in table $3 . \mathrm{Mg}^{2+}$ cannot replace $\mathrm{Zn}^{2+}$ at the zinc site to give an active enzyme, and $\mathrm{Zn}^{2+}$ causes an inhibition when it fixes on the magnesium site. $\mathrm{Mn}^{2+}$, and especially $\mathrm{Co}^{2+}$, may be favorably substituted for both $\mathrm{Zn}^{2+}$ and $\mathrm{Mg}^{2+}$.

In a previous study (Linden and Michalowski, 1976), we observed that human, sheep and bovine enzymes were hardly sensitive to L-Phe, but strongly inhibited by L-homoarginine and imidazol.

Using all these properties, milk alkaline phosphotases may be classed as belonging to the group activated by $\mathrm{Mg}^{2+}$ and not very sensitive to $\mathrm{L}$-phenylalanine. This group includes most mammalian alkaline phosphatases excepted those of intestinal and placental origin.

Some previously published results have been invalidated by this study : (i) milk alkaline phosphatase does not have pyrophosphatasic activity, (ii) the dominant fraction is in octamer form, (iii $\mathrm{Ca}^{2}$ ion is a strong activater.

As Got (1971), we believe the comparative study of milk alkaline phosphatase of different species is useful for distinguishing between the milk secretion enzymes and those of the blood. Moreover, a knowledge of the quaternary structure and the action of metallic ions will help us to understand the essential biochemical aspects of the difficult problem of regeneration after heat denaturation.

Reçu en jonvier 1978.

Acceptè en février 1978.

Acknowledgment. - We wish to heartily thank Professor Vert, Maternity Hospital of Nancy, who gave us the human milk and Mr. Assenat, Head of the laboratory of the "Société des Caves de Roquefort», who furnished the ewe milk.

Résumé. La purification de la phosphatase alcaline du lait a permis d'isoler une fraction dominante qui est douée de propriétés moléculaires et cinétiques sensiblement identiques dans les espèces humaine, bovine ef ovine : masse moléculaire de 170000 daltons, $\mathrm{pH}$ optimum, absence de spécificité de substrat. La variation de $\mathrm{Km}$ ef $\mathrm{V}$ avec le $\mathrm{pH}$ met en évidence deux pK de groupes ionisables : 8,6 et 9,0-9,3 ; les groupes concernés du site actif doivent être identiques pour les enzymes humaine, bovine et ovine.

Les trois phosphatases nécessitent deux types de métaux pour leur activité maximale : $\mathrm{Zn}^{2+}$ qui est essentiel et $\mathrm{Mg}^{2+}$ qui a un effet fortement activateur.

La stimulation par $\mathrm{Mg}^{2+}$ est $\mathrm{pH}$-dépendante. $\mathrm{Mg}^{2+}$ se fixe lentement à $\mathrm{pH}$ faiblement alcalin en induisant un changement conformationnel. $\mathrm{Mg}^{2+}$ augmente uniquement la vitesse maximale $\mathrm{V}$. Le site $\mathbf{M g}^{2+}$ est différent du site de fixation du substrat. $\mathrm{Mg}^{2+}$ peut être remplacé par $\mathrm{Mn}^{2+}, \mathrm{Co}^{2+}$ et $\mathrm{Ni}^{2+} ; \mathrm{Zn}^{2+}$ peut s'y fixer également mais inhibe l'activité.

Les expériences de reconstitution à partir de l'apophosphatase humaine, ovine ef bovine indique que $\mathrm{Mg}^{2+}$ seul ne régénère pas l'activité, par conséquent $\mathrm{Mg}^{2+}$ ne peut se substituer à $\mathrm{Zn}^{2+}$ au site zinc ; de même, $\mathrm{Zn}^{2+}$ seul ne peut pas régénérer l'activité et entre en compétition avec $\mathrm{Mg}^{2+}$ dès qu'il est en excès ; $\mathrm{Zn}^{2+}$ a une affinité supérieure à $\mathrm{Mg}^{2+}$ pour le site magnésium. Le cobalt peut bien se substituer à la fois au zinc et au magnésium. 


\section{References}

AHLERS J., 1974. Kinetics of alkaline phosphatase from pig kidney. Biochem. J., 141, 257-263.

ANDREWS P., 1964. Estimation of the molecular weights of proteins by sephadex gel-filtration. Biochem. J., 91, 222-223.

BRUNEL C., 1972. Sur la purification et les bropriétés de la phosphatase alcaline du cerveau. Thèse Doct. ès-Sci., Montpellier.

BRUNEL C., CATHALA G., 1972. Imidazole : an inhibitor of L-phenylalanine insensitive alkaline phosphatase of tissues other than intestine and placenta. Biochim. biophys. Acta, 268, 41 5-421.

BURUIANA L. M., DEMA A., 1969. Separation, polymorphism and kinetics of the cow milk phosphatase. Rev. roum. Biochim., 6, 275-282.

CATHALA G., BRUNEL C., CHAPPELET-TORDO D., LAZDUNSKI M., 1975. Bovine kidney alkaline phosphatase : catalytic properties, subunit interactions in the catalytic process and mechanism of $\mathrm{Mg}^{2+}$ stimulation. J. biol. Chem., 250, 6041-6046.

DAVIS B. J., 1964. Disc electrophoresis. II. - Method and application to human serum proteins. Ann. N. Y. Acad Sci., 121, 404-427.

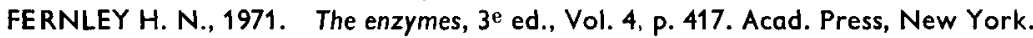

GHOSH N. K., FISHMAN W. H., 1968. Purification and properties of molecular-weight variants of human placental alkaline phosphatase. Biochem. J., 108, 779-792.

GOT R., 1971. Les enzymes des laits. Ann. Nutr. Alim., 25, A291-A311.

HELOUE M., 1974. Purification et éfude de quelques propriétés de la phosphatase alcaline du rein de bœuf. Thèse Spéc. Bioch., Montpellier.

HINBERG I., LAIDLER K. J., 1973. Influence of $\mathrm{pH}$ on the kinetics of reactions catalyzed by alkaline phosphatase. Canad. J. Biochem., 51, 1096-1103.

HIWADA K., WACHSMUTH E. D., 1974. Catalytic properties of alkaline phosphatase from pig kidney. Biochem. J., 141, 283-291.

LEFRANC G., HAN K., 1967. Isolement et purification de deux fractions de la phosphatase alcaline du lait de vache. Ann. Inst. Pasteur Lille, 18, 185-196.

LINDEN G., 1977. La phosphafase alcaline du lait : purification, propriétés et éfude du centre actif. Thèse Doct. ès-Sci, Nancy.

LINDEN G., ALAIS C., 1976. Phosphatase alcaline du lait de vache. II. Structure sous-unitaire, nature métalloprotéique et paramètres cinétiques. Biochim. biophys. Acta, 429, 205-213.

LINDEN G., CHAPPELET-TORDO D., LAZDUNSKI M., 1977. Milk alkaline phosphatase : stimulation by $\mathrm{Mg}^{2+}$ and properties of the $\mathrm{Mg}^{2+}$ site. Biochim. biophys. Acta, 483, 100-106.

LINDEN G., GED J., 1976. Activité, polymorphisme et origine de la phosphatase alcaline dans le lait. Milchwiss. 31, 724-728.

LINDEN G., MICHALOWSKI J. B., 1976. Action de la L-phénylalanine ef d'autres acides aminés sur l'activité de la phosphatase alcaline du lait. Milchwiss., 31, 78-80.

MICHALOWSKI J. B., 1977. La phosphotase alcaline des laits humain ef ovin ; purification, propriétés, action des ions métalliques. Thèse Spéc. Bioch., Nancy.

MORTON R. K., 1953. Alkaline phosphatase of milk : 2. purification of the enzyme. Biochem. J., 55, 795-800.

MOSS D. W., WHITBY L. G., 1975. A simplified heat-inactivation method for investigating alkaline phosphatase iosenzymes in serum. Clin. chim. Acta, 61, 63-71.

PEEREBOOM J. W. C., 1968. Studies on alkaline milk phosphatase. Il. Occurrence of various phosphatase isoenzymes in dairy products. Neth. Milk. Dairy J., 22, 137-152.

PETITCLERC C., DELISLE M., MARTEL M., FECTEAU C., BRIĖRE N., 1975. Mechanism of action of $\mathrm{Mg}^{2+}$ and $\mathrm{Zn}^{2+}$ on rat placental alkaline phosphatase. I. Studies on the soluble $\mathrm{Zn}^{2+}$ and $\mathrm{Mg}^{2+}$ alkaline phosphatase. Canad. J. Biochem., 53, 1089-1100.

SANDERS S. P., 1949. The phosphatase test for pasteurization of dairy products. C. R. $12^{\mathrm{e}}$ Congr. int. Lait, Stockholm, 2, 757-765.

WEBER K., OSBORN M., 1969. The reliability of molecular weight determinations by dodecyl sulfate-polyacrylamide gel electrophoresis. J. biol. Chem., 244, 4406-4412. 